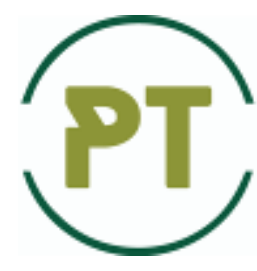

\title{
Research of Wear Resistance of a Covering of Shafts of the Turbocharger of the Diesel Engine Restored by Means of a Gas-Dynamic Spraying
}

\author{
D.D. Marchenko*, K.S. Matvyeyeva \\ Mykolayiv National Agrarian University, Ukraine \\ *E-mail: marchenkodd@mnau.edu.ua
}

Received: 10 May 2021: Revised: 15 August: Accept: 20 September 2021

\begin{abstract}
The analysis of tribological researches on the most perspective way of restoration of a primary resource of engines by means of a gas-dynamic spraying is resulted in article. It was found that to reduce the coefficient of friction and increase the wear resistance of the coating is theoretically justified the use of copper-zinc powders brand C-01-11, applied by gas-dynamic spraying. It is established that the physical and mechanical properties of the coatings (roughness, microhardness, friction coefficient) on the restored turbocharger meet the requirements of the manufacturer. The coefficient of friction in the connection, the rotor shaft (reduced powder with copper and zinc), with a plain bearing (made of tin-lead bronze Bros - 10 - 10) is $20 \%$ less than in the connection where the rotor shaft is made of steel 40 . The total wear in the bearing assembly with the restored gas-dynamic sprayed rotor shaft is $20 \%$ lower than in the assembly where the rotor shaft is restored by the basic technology. The technology of restoration of a surface of a shaft of a rotor of the turbocompressor, under the bearing of sliding (gas-dynamic spraying) which increases its resource by $23 \%$ in comparison with basic technology of repair of a shaft of a rotor is developed. This allows you to increase its operating time with the established regulatory and technical documentation for overhaul of the engine. A stand for testing diesel turbochargers with recovery technology has been developed, which allows to determine the parameters and characteristics of diesel engine turbochargers in different periods of operation, running-in and adjustment. Tests on the stand showed that turbochargers with restored rotor shafts according to the proposed technology after 2000 operating hours increase all performance by $13 \%$ more than turbochargers repaired by the basic technology. Operational tests have shown that turbochargers repaired using the proposed technology have an operating time of 989 moto-hours more than turbochargers repaired with existing technology.
\end{abstract}

Key words: gas-dynamic spraying, wear resistance, friction steam, turbocharger, recovery technology, wear intensity.

\section{Introduction}

At the present stage of economic development of Ukraine there are questions of design, production and efficient operation of existing machinery and equipment. Improving the efficiency of the existing fleet of machines can be achieved by increasing the efficiency of equipment, reducing the cost of its operation and reducing downtime for technical reasons [1].

The fleet of tractor and agricultural machinery, as well as mobile diesel power plants used in the agroindustrial complex, is now characterized by accelerating its moral and material wear. This increases the intensity of machine failures and the duration of downtime associated with the restoration of their efficiency, increasing the cost of unscheduled maintenance and repair (TE and P).

The main power unit of almost any machine used in agricultural trials is a diesel. The analysis showed that the least reliable unit of the diesel engine is a turbocharger (TCR). It accounts for more than $15 \%$ of engine failures. In turn, more than $80 \%$ of TCR failures are due to the bearing assembly of the rotor shaft [2, 3]. The difficulty of repairing turbochargers of tractor and agricultural machinery is that the areas where the equipment 
is operated are remote from the repair and maintenance bases. To reduce machine downtime for technical reasons, it is necessary to increase the turbocharger to the value set by the regulatory and technical documentation for TE and $\mathrm{P}$ engine.

Analysis of ways to increase the efficiency of friction joints shows that the most promising for the repair of the bearing assembly of the turbocharger is to restore the seating surface of the rotor shaft of the turbocharger with materials that reduce the load on the unit.

\section{Literature review}

Repair of agricultural machinery by $70-80 \%$ is carried out using spare parts, while downtime of machines due to their lack or low quality leads to large losses of agricultural products. The cost of spare parts is constantly growing and therefore the restoration of worn parts with the provision of their resource at the level of new - one of the most effective ways to save money. According to GOSNITI 85\% of details, at their defectation, have wear no more than $0,3 \mathrm{~mm}$, ie their working capacity is restored at drawing of coverings of insignificant thickness. However, the life of refurbished parts, compared to new parts, in many cases remains low [4].

Scientists and specialists from such organizations as TsNIIME, SPKTB Soyuzlesremmash (GNTSLPK), MGUL, VLTA and others carried out a large amount of work to organize and improve the technical level of operation of forest machines and repair work in the industry. Among them V.V. Balikhin, V.V. Bykov, I.V. Voskoboinikov, V.N. Vinokurov, V.A. Goberman, N.S. Eremeev, V.M. A. V. Kotikov Pitukhin, A.V. Serov and others.

To increase the net power of internal combustion engines, the most effective currently is the installation of a turbo compressor. The turbocharger increases engine power by $30 \%$ without increasing its displacement.

The turbocharger is also the least reliable part of a diesel engine. More than $60 \%$ of failures are due to the turbocharger. Table 1 shows the share of failures using the example of the repeatability factor of the main elements of a turbocharger. About $81 \%$ of turbocharger failures are caused by it.

Table 1

\section{The results of laboratory tests for wear resistance of friction pairs}

\begin{tabular}{|c|l|l|l|c|}
\hline Stationary specimen & \multicolumn{1}{|c|}{ Moving specimen } & $I_{\kappa}$ & $I_{p}$ & $I_{\Sigma}$ \\
\hline Tin-lead bronze BrOS-10-10 & Steel 40 & $7.14 \cdot 10^{-11}$ & $4.23 \cdot 10^{-11}$ & $1.37 \cdot 10^{-10}$ \\
\hline Tin-lead bronze BrOS-10-10 & Nickel-plated coating & $1.27 \cdot 10^{-11}$ & $1.57 \cdot 10^{-11}$ & $2.84 \cdot 10^{-11}$ \\
\hline Tin-lead bronze BrOS-10-10 & Copper-zinc coating & $0.74 \cdot 10^{-11}$ & $1.38 \cdot 10^{-11}$ & $2.12 \cdot 10^{-11}$ \\
\hline
\end{tabular}

At the same time; there are examples when the resource of parts restored by progressive methods is several times higher than the resource of new parts. When choosing a method of restoring parts, it is necessary to ensure high quality coatings, low cost of the process, minimum material consumption, labor and energy costs. At the same time it is necessary to concentrate the attention on such ways which increase reliability not only details, but also all assembly unit as a whole [5].

The main trend in the development of modern tractors and combines; engines - increase of aggregate capacities at practical preservation of their weight and dimensions due to application of turbocharging. High technical and economic indicators of gas turbine supercharging, as a way to increase power by $15 \ldots 30 \%$, led to its widespread use in tractor and combine engines. At present, all combine and multi-tractor engines (SMD60/61, SMD-62/63, SMD-64/65, SMD-66/67, SMD-31/32, SMD-17/18, etc.) are provided with gas turbine supercharging. For supercharging of these engines turbocompressors of the standard sizes are used: TKR - 11 (with external diameter of a wheel of the compressor Dk $=110 \mathrm{~mm}$ ), TKR-9 (with Dk $=90 \mathrm{~mm}$ ), TKP $-8,5$ (with $\mathrm{Dk}=85 \mathrm{~mm}$ ), TKP -7 (with $\mathrm{Dk}=70 \mathrm{~mm}$ ).

Experience in operation of turbochargers type TKP - 11, installed on engines SMD-60/61, SMD-62/63, SMD-64/65; SMD-66/67, SMD-31/32, SMD-17/18, YAME-238NB, YaMZ-240NB shows that this unit is the least durable unit. Thus, according to GOSNIT, the number of turbocharger failures is $2 \ldots 13 \%$ of the total number of engine failures. The life of the repaired turbocharger is only $62 \%$ of the life of the new one [6].

Currently, there are two main areas in the repair of worn parts of turbochargers. The most common methods - installation of repair parts, the method of repair dimensions, plastic deformation. Rarely used on the surface of the layer: metal, compensating for the amount of wear (galvanic, surfacing methods).

All existing methods, along with the advantages, have certain disadvantages. When repairing turbochargers, it is necessary to restore parts made of different materials (steel, bronze, aluminum alloy) and different configurations; (planes, cylindrical outer and inner surfaces). In this regard, to restore worn parts, you need a large range of equipment used [7,8].

To improve the quality of repair and increase the service life of overhauled turbochargers, it is necessary to develop a recovery technology that ensures durability and trouble-free operation of the unit for the period before overhaul of the diesel engine on which this turbocharger is installed [9]. 
One of the promising ways to restore the primary life of the engines is gas-dynamic spraying, but the practical application for the restoration of smooth cylindrical surfaces on the example of the rotor shaft of the turbocharger, this method did not work. Therefore, the task is to theoretically substantiate the increase in the total wear resistance of the node "rotor shaft - plain bearing" and develop a method of restoring the surface of the rotor shaft, which will increase the turbocharger to overhaul the engine.

\section{Purpose}

The purpose of the research is to increase the reliability of turbochargers for diesel tractors and agricultural machinery by increasing the service life of the rotor shaft.

\section{Research methodology}

To determine the coefficient of friction and assess the intensity of wear, a set of laboratory tests was performed, including checking the properties of the surface (hardness, roughness) and testing for the intensity of wear on the friction machine.

A stand for overhaul tests of overhauled turbochargers was developed for bench tests.

For research, turbochargers were removed from diesels operated on farms. Next, the turbochargers underwent a recovery procedure using the proposed technology. The repaired turbochargers were tested on a stand of our own design, according to our proposed new method. To pass operational tests, turbochargers were installed on tractors operated on farms [10].

The wear resistance of the coating is the most important criterion for assessing the service life of a combination exposed to friction. Its value is greatly influenced by the physical and mechanical properties of the coatings, the state of roughness and microhardness of the surface layer of the joint, as well as the coefficient of friction and the load force acting on the joint.

When measuring the roughness of the coating, it was found that after testing in the reduced shaft of the rotor coated with powder C-01-11, the roughness parameter for Ra was $0.235 \mu \mathrm{m}$, which is significantly less than in other test samples. Reducing the value of surface roughness significantly reduces the intensity of wear. During the bench tests, the turbocharger was disassembled at intervals of 100 moto-hours. The value of the roughness parameter did not change with increasing operating time.

\section{Research results}

During tribotechnological laboratory tests on the AI-5018 friction machine, measurements of various parameters at simulation of various types of work of the engine were made. In fig. 1 shows the dependence of the change in the coefficient of friction in the test materials under the influence of simulating the dynamic load.

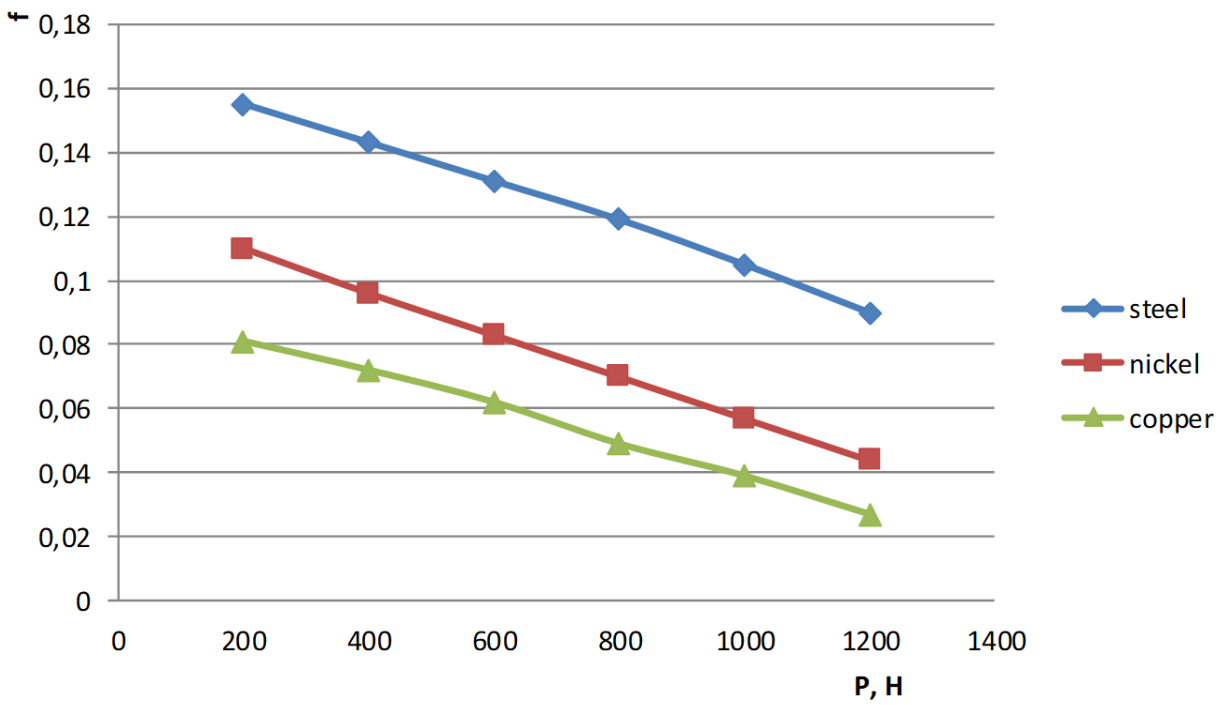

Fig. 1. Dependence of change of coefficient of friction on force, acting on the connection

From the presented dependence it follows that the rotor shaft of the turbocharger coated with copper-zinc powder brand C-01-11 has a lower coefficient of friction than a standard shaft made of steel or a shaft having a nickel coating $\mathrm{N}-00-14$. This is due to the fact that initially the basic coefficient of friction in copper is lower than in nickel and especially steel. 
After a comparative assessment of the mutual wear intensity of the rotation pairs, the dependences of the change in the wear intensity were revealed [11]. In fig. 2 shows the total wear intensity of the samples after testing for wear resistance on the friction machine AI - 5018. In table 1 shows the wear intensity of the rotor roller, simulating the shaft, and the pad, which simulates a plain bearing when tested on a friction machine.

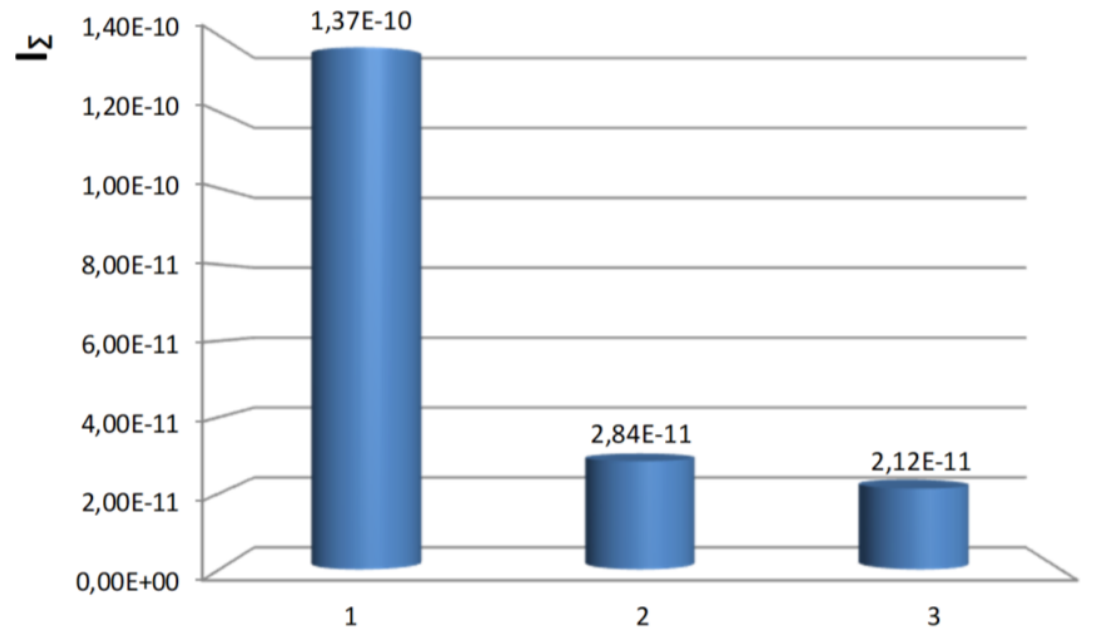

Fig. 2. The total wear intensity of the experimental samples:

$$
\begin{aligned}
& 1 \text { - steel with bronze; } \\
& 2 \text { - nickel with bronze; } \\
& 3 \text { - copper with bronze }
\end{aligned}
$$

The diagram shows that the wear rate of the bearing assembly, restored by gas-dynamic spraying with copper-zinc powder is seven times less than the standard friction pair of steel with bronze.

Wear intensity in friction pairs "copper-zinc - BrOS-10-10" is 4 times less than in pairs "steel - BrOS-10-10".

Comparative tests of turbochargers repaired by the proposed method of gas-dynamic spraying and turbochargers repaired by existing technology, on the stand for acceptance tests, showed that turbochargers repaired by the proposed method provide the main performance [12].

In fig. 3 presents the results of processing changes in the main operating parameters of the turbocharger, which affect the performance of the engine.

From the graphs it turns out that the turbocharger, repaired by the proposed technology has after running in 2000 moto-hours. the main operating parameter, the air pressure in the combustion chamber is $13.6 \%$ higher than that of turbochargers repaired by previously existing technology, and vibration acceleration increases by $12.4 \%$. Development of the turbocharger of these characteristics allows to operate equipment without carrying out unplanned repairs [13].

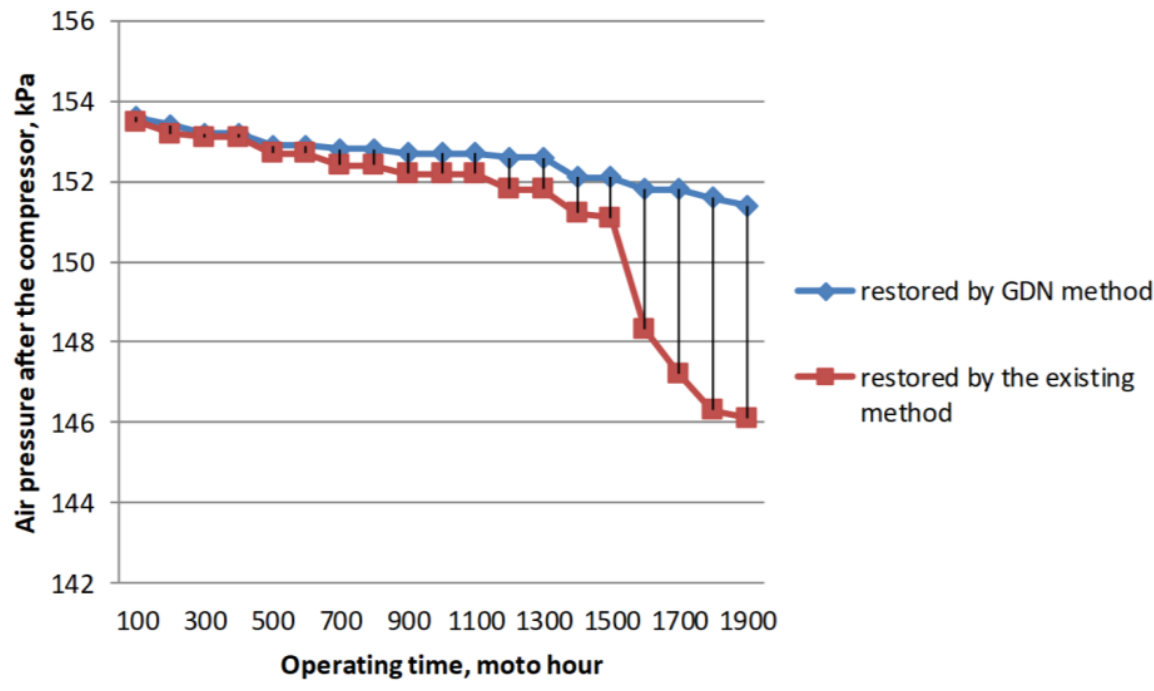




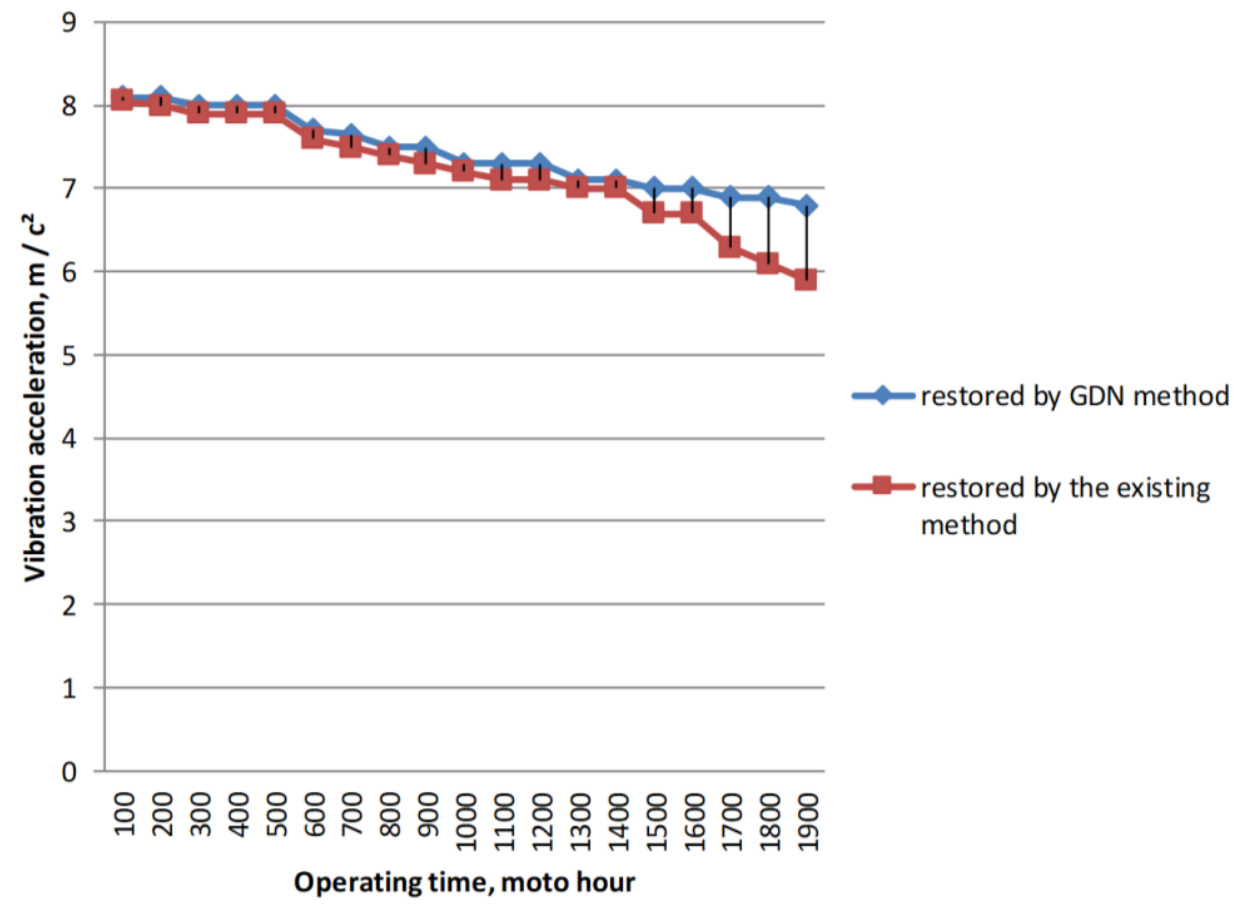

b

Fig. 3. The main operating parameters of the turbocharger: a-air pressure in the combustion chamber; b - vibration acceleration

After statistical data processing, the scatter of the main performance of the turbocharger was.

During operation, the equipment worked in normal modes, without which or complaints about the instability of the turbochargers. Operating time was $900 \ldots 2000$ moto-hours. At the enterprises where the tested turbochargers were tested, they received positive recommendations for their work [14]. After testing, the turbochargers were disassembled and measured the wear of the shaft surface under the plain bearing. Mutual wear on the new turbochargers in the bearing assembly was $35 \%$ of the limit, and in the bearing assembly, restored by gas-dynamic spraying, was $15 \%$ of the limit.

\section{Conclusions}

The analysis of literature and information materials showed that during the operation of the internal combustion engine the turbocharger is the most loaded. The most common failure is the wear of the bearing assembly of the turbocharger, their share in the total number of failures is $81 \%$. Restoration of the bearing unit with increased wear resistance is the most urgent task. Existing methods of recovery are either expensive or do not provide the required durability. One of the most promising ways to restore the primary life of engines is gasdynamic spraying. To reduce the coefficient of friction and increase the wear resistance of the coating, the use of copper-zinc powders brand C-01-11, applied by gas-dynamic spraying, is theoretically justified.

As a result of the conducted researches the necessary recommendations on the technique of tests of turbochargers were made. The development complements and develops the capabilities of the defect system and calibrates in terms of improving the efficiency and ease of operation of bench equipment during repair and maintenance of turbines.

Thus, the technical feasibility of using the technology of recovery by gas-dynamic spraying and the choice of copper-zinc powder brand C-01-11 for coating the rotor shaft of the turbocharger.

\section{References}

1. McCune R.C. An Exploration of the Cold Gas Dynamic Spray Method for Several Materials Systems / R.C.McCune, A.N.Papyrin, J.N.Hall, W.L.Riggs, P.H.Zajchowski // Proc. 8th NTSC 11-15 Sept. 1995, Houston, Texas, USA, p.1-6.

2. Segal A.E. A Cold-Gas Spray Coating Process for Enhancing Titanium / A.E.Segal, A.N.Papyrin, J.C.Conwey, and D.Shapiro // JOM, vol.50, N 9, Sept., 1998, p. 52-54.

3. Dykhuizen R.C. Gas Dynamic Principles of Cold Spray / R.C.Dykhuizen and M.F.Smith // Journal of Thermal Spray Technology, June 1998, Vol. 7, No. 2, p. 205212. 
4. Van Steenkiste T.H. Aluminum coatinga via kinetic spray with relatively large powder particles / T.H.Van Steenkiste, J.R.Smith, R.E.Teets // Surface and Coatings Technology, 2002, vol.154, p.237-252.

5. Jodoin B. Effects of Shock Waves on Impact Velocity of Cold Spray Particles / B.Jodoin // Proc. International Thermal Spray Conference and Exposition "Advancing Thermal Spray in the 21st Century", Singapore, May 28 30, 2001, p.399 - 407.

6. Thorpe M.L. Hight pressure HVOF an update / M.L. Thorpe, R.J. Thorpe // Proc. of the 1993 National Thermal Spray Conf., Anahiem, C A, 7-11 june, 1993. - Anahiem, 1993.

7. Hackett C.M. On the gas dynamics of HVOF thermal sprays / C.M. Hackett, G.S. Settles, J.D. Miller // Proc. of the 1993 National Thermal Spray Conf., Anahiem, CA, 7-11 june, 1993. Anahiem, 1993.

8. Stoltenhoff T. Cold spraying state of the art and applicability / T.Stoltenhoff, J.Voyer and H.Kreye // Proc. International Thermal Spray Conference 2002 (ITSC 2002), Essen, Germany, March 4-6, 2002, p.385 393.

9. Marchenko D.D. Improving the contact strength of V-belt pulleys using plastic deformation / D.D. Marchenko, K.S. Matvyeyeva // Problems of Tribology. - Khmelnitsky, 2019. - Vol 24. - No 4/94 (2019) - S. 49-53. DOI: https://doi.org/10.31891/2079-1372-2019-94-4-49-53.

10. Richter P. Equipment engineering and process control for cold spraying / P. Richter, D.W. Krommer and P. Heinrich // Proc. International Thermal Spray Conference 2002 (ITSC 2002), Essen, Germany, March 46 , 2002, p.394 - 398.

11. Marchenko D.D. Investigation of tool wear resistance when smoothing parts / D.D. Marchenko, K.S.Matvyeyeva // Problems of Tribology. - Khmelnitsky, 2020. - Vol 25. - No 4/98 (2020) - S. 40-44. DOI: https://doi.org/10.31891/2079-1372-2020-98-4-40-44

12. Dykha A.V. Study and development of the technology for hardening rope blocks by reeling. ISSN 1729-3774 / A.V. Dykha, D.D. Marchenko, V.A. Artyukh, O.V. Zubiekhina-Khaiiat, V.N. Kurepin // EasternEuropean Journal of Enterprise Technologies. Ukraine: PC «TECHNOLOGY CENTER». - 2018. - №2/1 (92) 2018. - pp. 22-32. DOI: https://doi.org/10.15587/1729-4061.2018.126196.

13. Dykha A.V. Prediction the wear of sliding bearings. ISSN 2227-524X / A.V. Dykha, D.D. Marchenko // International Journal of Engineering and Technology (UAE). India: "Sciencepubco-logo" Science Publishing Corporation. Publisher of International Academic Journals. - 2018. - Vol. 7, No 2.23 (2018). - pp. 4-8. DOI: https://doi.org/10.14419/ijet.v7i2.23.11872.

14. Marchenko D.D. Analysis of the influence of surface plastic deformation on increasing the wear resistance of machine parts / D.D. Marchenko, V.A. Artyukh, K.S. Matvyeyeva // Problems of Tribology. Khmelnitsky, 2020. - Vol 25. - No 2/96 (2020) - S. 6-11. DOI: https://doi.org/10.31891/2079-1372-2020-96-26-11. 
Марченко Д.Д., Матвєєва К.С. Дослідження зносостійкості покриття валів турбокомпресора дизельного двигуна відновленими за допомогою газодинамічного напилення.

В статті приведено аналіз трибологічних досліджень 3 найбільш перспективного способу відновлення первинного ресурсу двигунів за допомогою газодинамічного напилення. Виявлено, що для зниження коефіцієнта тертя і підвищення зносостійкості покриття теоретично обгрунтовано застосування мідно-цинкових порошків марки C-01-11, нанесених методом газодинамічного напилення. Встановлено, що фізико-механічні властивості покриттів (шорсткість, мікротвердість, коефіцієнт тертя) на відновленому турбокомпресорі відповідають вимогам заводу виготівника. Коефіцієнт тертя в з'єднанні, вал ротора (відновлений порошком мідь 3 цинком), з підшипником ковзання (з олов'янистосвинцевої бронзи Брос - 10 - 10) на $20 \%$ менше, ніж у з'єднання, де вал ротора виготовлений із сталі 40. Сумарний знос в підшипниковому вузлі з відновленим газодинамічним напиленим валом ротора на $20 \%$ нижче, ніж у вузлі, де вал ротора відновлений за базовою технологією. Розроблена технологія відновлення поверхні валу ротора турбокомпресора, під підшипник ковзання (газодинамічним напиленням), яка збільшує його ресурс на 23 \% в порівнянні з базовою технологією ремонту валу ротора. Це дозволяє збільшити його напрацювання встановленою нормативно-технічною документацією на капітальний ремонт двигуна. Розроблено стенд для випробування турбокомпресорів дизелів при технології відновлення, який дозволяє визначити параметри i характеристики турбокомпресорів дизельних двигунів в різні періоди експлуатації, обкатки і регулювання. Випробування на стенді показали, що турбокомпресори з відновленими валами роторів за запропонованою технологією після 2000 мото-год напрацювання підвищують усі робочі характеристики на $13 \%$ більше, ніж турбокомпресори, відремонтовані за базовою технологією. Експлуатаційні випробування показали, що турбокомпресори, відремонтовані за запропонованою технологією мають напрацювання на 989 мото-год більше, ніж турбокомпресори, відремонтовані за існуючою технологією.

Ключові слова: газодинамічне напилення, зносостійкість, пара тертя, турбокомпресор, технологія відновлення, інтенсивність зношування. 